\title{
Pengembangan Knowledge Management System Berbasis Knowledge Audit
}

\author{
Panji Madya Ramdani \\ AMIK BSI Jakarta \\ email: panji.pmr@bsi.ac.id
}

\begin{abstract}
Abstrak
Dasar dari sumber daya ekonomi saat ini bukan lagi berupa modal uang, sumber daya alam maupun tenaga kerja melainkan juga pengetahuan (knowledge). Pengetahuan sebagai intangible asset yang harus dikelola perusahaan menjadi paradigma baru dalam lingkungan bisnis sebagai pusat kekuatan dan keunggulan dalam bersaing. Namun masih banyak organisasi belum atau tidak mengetahui potensi pengetahuan yang dimiliki oleh karyawannya karena organisasi kesulitan dalam menangkap (capture) tacit knowledge. Lambatnya penyebaran pengetahuan disebabkan oleh terbatasnya ruang dan waktu. Transfer knowledge hanya menggunakan metode tatap muka, konsultasi secara langsung dengan atasan, dan briefing pagi (socialization-tacit totacit). Adapun Explicit knowledge hanya terdapat dalam bentuk berkas (hardcopy), dimana terdapat kesulitan dalam proses pencarian. Penelitian ini telah berhasil mempermudah transfer knowledge di dalam perusahaan melalui pengembangan knowledge management system berbasis knowledge audit dengan knowledge management processes sebagai standar pengembangan. Audit yang dihasilkan telah mampu mengidentifikasi kompetensi dan kapabilitas dari karyawan, serta mengoptimalisasi mekanisme knowledge management yang ada di organisasi.
\end{abstract}

Kata kunci: Tacit Knowledge, Explicit Knowledge, Knowledge Audit, Knowledge Management System.

\begin{abstract}
The basic economic resources now adays is no longer capital, natural resources, nor labor, but also knowledge. Knowledge as intangible asset, that need to be managed by organization became new paradigm in the business environment where knowledge is now considered to be central to organizational performance and integral to the attainment of a sustainable competitive advantage. Many organizations still do not realize the knowledges and experiences their employees had. It happens because the organizations have difficulties in detecting the tacit knowledge, thus the sharing of knowledge and experience did not run smoothly. If the employees had to share what they know then they do it by meeting face to face with their superior or share it in the morning briefing.Time and spaces are still the main problems in this case. Explicit knowledge only shared in form of a hardcopy archives, while there is also a problem in archiving files within the organization. This research has succeeded in easing the transfer of knowledge through knowledge management system with knowledge audit as a base and knowledge management process as a development standard. The audit result has the capability in identifying competence and capability of the workers, and also optimize the existing knowledge management mechanism within the organization.
\end{abstract}

Keywords: Tacit Knowledge, Explicit Knowledge, Knowledge Audit, Knowledge Management System 


\section{Pendahuluan}

Persaingan global saat ini semakin ketat, serta perkembangan ilmu pengetahuan dan teknologi yang sangat pesat, menuntut perusahaan untuk lebih efektif, efisien dan inovatif. Inovasi adalah keberhasilan dalam meng-eksploitasi ide-ide baru menjadi suatu produk atau proses. Sementara untuk mempercepat penemuan produk yang baru dan inovasi semakin tergantung pada penggunaan informasi dan teknologi pengetahuan yang canggih untuk membangun lingkungan yang mendukung proses inovasi yang sistematis dan efisien (Specht, Beckmann, \& Amelingmeyer, 2002; Amidon, 2002).

Sedangkan dasar dari sumber daya ekonomi saat ini bukan lagi berupa modal uang, sumber daya alam maupun tenaga kerja melainkan juga pengetahuan (Peter $\mathrm{F}$. Drucker, 1998). Pengetahuan sebagai intangible asset yang harus dikelola perusahaan menjadi paradigma baru dalam lingkungan bisnis sebagai pusat kekuatan dan keunggulan dalam bersaing yang harus dikelola perusahaan yang menjadi paradigma baru dalam lingkungan bisnis sebagai pusat kekuatan dan keunggulan dalam bersaing (Davenport \& Grover, 2001; Peter F Druker, 1998). Dalam pengelolaan pengetahuan (Knowledge Management), telah digunakan berbagai model dan kerangka kerja untuk mewakili alur pengetahuan dalam suatu organisasi.

Metode yang pertama dan paling popular dalam Knowledge Management yaitu konversi pengetahuan atau lebih dikenal SECI Model (Socialization, Externalization, Combination, Internalization) model yang dipaparkan oleh Nonaka dan Takeuchi (1995), Nonaka dan Konno (1998), Nonaka dan Toyama (2003), yang menyajikan berbagai pengetahuan interaksi dan kreasi antara pengetahuan terbatinkan (tacit knowledge) dan pengetahuan yang terkodifikasi (explicit knowledge). Nonaka dan Takeuchi (1995) telah menganalisis proses penciptaan pengetahuan pada organisasi di Jepang, dan mengembangkan kerangka kerja (SECI model).

Namun, masih banyak organisasi belum atau tidak mengetahui potensi pengetahuan dan tacit knowledge yang dimiliki oleh karyawannya. Riset Delphi Group (Setiarso, Bambang dkk. , 2009) menunjukkan bahwa pengetahuan dalam organisasi tersimpan dalam struktur: a. $42 \%$ dipikiran (otak) karyawan, b. $26 \%$ dokumen kertas, c. $20 \%$ dokumen elektronik, d.12\% knowledge base elektornik.

\section{Metode Penelitian}

Penelitian ini menggunakan metode analisis deskriptif yang bertujuan untuk mendapatkan gambaran yang lebih mendalam dan lengkap dari obyek penelitian, dengan melakukan pengamatan serta wawancara langsung di lapangan.

Ada beberapa tahapan penting dalam penelitian ini, diantaranya adalah sebagai berikut:

a. Tahap 1: Pemilihan Permasalahan

Penelitian dimulai dengan mengidentifikasi domain permasalahan, pada penelitian ini yang menjadi inti permasalahan bahwa banyak organisasi belum atau tidak mengetahui potensi pengetahuan dan tacit knowledge yang dimiliki oleh karyawannya. Merujuk hasil riset yang dilakukan oleh Delphi Group (Setiarso, Bambang dkk., 2009), menunjukkan bahwa pengetahuan dalam organisasi persentase terbesar dalam bentuk tacit knowledge. Dimana organisasi kesulitan dalam menangkap (capture) dan menyebarkan/kodifikasi dari tacit knowledge tersebut.

b. Tahap 2: Analisis Penelitian Terdahulu Untuk menjaga originalitas dari penelitian, maka diperlukan studi literatur terhadap penelitian-penelitian terdahulu yang relevan dengan penelitian ini. Hal ini juga berguna sebagai alat pemetaan atau identifikasi posisi penelitian yang akan dilakukan. Setelah dikumpulkan sejumlah penelitian yang dinilai relevan dengan penelitian ini baik yang berasal dari dalam negeri maupun luar negeri, maka selanjutnya adalah memilih penelitian-penelitian mana saja yang memiliki kontribusi cukup besar terhadap proses pencapaian tujuan dari penelitian ini.

c. Tahap 3: Pemodelan Bisnis Proses Organisasi/Kondisi Organisasi saat ini Pemodelan bisnis proses sangat penting, hal ini dikarenakan apabila dalam penelitian telah terlebih dahulu mengetahui proses bisnis dari organisasi, maka akan dengan mudah diperoleh pembatasan masalah yang sesuai dengan tujuan penelitian.

d. Tahap 4: Pengembangan Metode Penelitian

Penelitian ini berusaha untuk melakukan beberapa modifikasi terhadap penelitian maupun model terdahulu, dengan menggunakan metode knowledge audit (Liebowitz, J., Montano, B.R., McCaw, D., 
Buchwalter, J., \& Browning C,.2007) dengan metode knowledge management processes (Beccerra-Fernandez, Gonzalez, A. \& Sabherwal, R. 2004) sebagai acuan standar dalam pengembangan knowledge management system untuk memudahkan mengidentifikasi pengetahuan dan knowledge management system yang sudah berjalan di organisasi
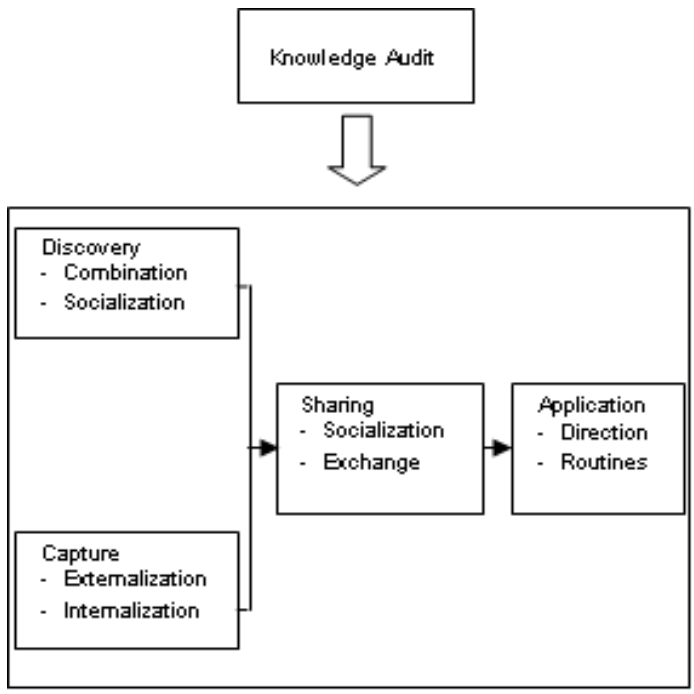

Gambar 1. Pengembangan Metode Penelitian

Dari hasil audit akan diketahui pengetahuan yang ada dan yang hilang atau pengetahuan yang terlewatkan, serta dapat diketahui knowledge management processes yang berjalan pada organisasi sudah sejauh mana. Selanjutnya dilakukan perancangan model alur dan proses dari pengelolaan pengetahuan mengacu penelitian BeccerraFernandez, Gonzalez, A. \& Sabherwal, R. (2004) yang dijadikan sebagai acuan standard pengembangan. Sehingga memudahkan atau memperbaiki knowledge management system yang ada sebelumnya pada organisasi. Penjelasan lebih lanjut dapat dilihat pada tabel 1 berikut:

Tabel 1. Analisa Literatur dan Posisi Penelitian

\begin{tabular}{|c|l|}
\hline Penelitian & \multicolumn{1}{|c|}{ Hasil Penelitian } \\
\hline Liebowitz, J., & Menjelaskan langkah- \\
Montano, & langkah dan instrumen \\
B.R., & dalam knowledge audit, \\
McCaw, D., & untuk mengidentifikasi \\
Buchwalter, & pengetahuan yang ada, \\
J., \& & pengetahuan yang \\
Browning C,. & berpotensi hilang, siapa \\
\hline
\end{tabular}

\begin{tabular}{|c|c|}
\hline Penelitian & Hasil Penelitian \\
\hline (2007) & $\begin{array}{l}\text { yang membutuhkan dari } \\
\text { pengetahuan tersebut dan } \\
\text { yang akan } \\
\text { menggunakannya. Dimana } \\
\text { hasil dari audit sebagai } \\
\text { rekomendasi kepada pihak } \\
\text { manajemen sebagai } \\
\text { perbaikan dalam aktivitas } \\
\text { knowledge management }\end{array}$ \\
\hline $\begin{array}{c}\text { Beccerra- } \\
\text { Fernandez, } \\
\text { Gonzalez, A. } \\
\& \\
\text { Sabherwal, } \\
\text { R. } 2004\end{array}$ & $\begin{array}{l}\text { Menjelaskan alur dan proses } \\
\text { dari manajemen pengelolaan } \\
\text { pengetahuan pada } \\
\text { organisasi yang lebih } \\
\text { spesifik pada proses capture } \\
\text { dan penggunaan kembali, } \\
\text { serta bagaimana } \\
\text { pengetahuan disimpan dan } \\
\text { bagaimana penggunaan } \\
\text { pengetahuan secara efektif }\end{array}$ \\
\hline Penelitian ini & $\begin{array}{l}\text { 1. Pengembangan proses } \\
\text { dalam pengembangan } \\
\text { knowledge management } \\
\text { system dengan } \\
\text { melakukan knowledge } \\
\text { audit (Liebowitz, J., } \\
\text { Montano, B.R., McCaw, } \\
\text { D., Buchwalter, J., \& } \\
\text { Browning C,. 2007) } \\
\text { untuk mengidentifikasi } \\
\text { pengetahuan dan } \\
\text { knowledge management } \\
\text { yang ada pada } \\
\text { organisasi dengan } \\
\text { knowledge management } \\
\text { processes (Beccerra- } \\
\text { Fernandez, Gonzalez, A. } \\
\text { \& Sabherwal, R. 2004) } \\
\text { sebagai acuan standar } \\
\text { dalam pengembangan } \\
\text { knowledge management } \\
\text { system. } \\
\text { 2. } \text { Dari hasil audit dilakukan } \\
\text { perancangan model alur } \\
\text { dan proses dari } \\
\text { pengelolaan } \\
\text { pengetahuan mengacu } \\
\text { penelitian Beccerra- } \\
\text { Fernandez, Gonzalez, A. } \\
\text { \& Sabherwal, R. (2004) } \\
\text { sebagai acuan standar } \\
\text { pengembangan. } \\
\text { Sehingga memudahkan } \\
\text { atau memperbaiki } \\
\text { knowledgemanagements } \\
\text { ystem yang ada } \\
\text { sebelumnya pada } \\
\text { organisasi. }\end{array}$ \\
\hline
\end{tabular}


e. Tahap 5: Knowledge Audit

Melakukan audit dengan menggunakan instrument penelitian berupa angket atau kuesioner guna memperoleh data yang dibutuhkan dengan acuan kajian Knowledge Audit Liebowitz, J., Montano, B.R., McCaw, D., Buchwalter, J., \& Browning C,. (2007) dan Knowledge Management Processes Beccerra-Fernandez, Gonzalez, A. \& Sabherwal, R. (2004) sebagai acuan standar dalam pengembangan knowledge management system. Kuesioner terdiri dari dua set, set pertama digunakan untuk mengidentifikasi pengetahuan yang ada dan pengetahuan yang berpotensi hilang atau terlewatkan, mengidentifikasi sumber pengetahuan, alur atau proses pengelolaan pengetahun yang ada, serta mengidentifikasi hambatan pada knowledge management system yang ada pada organisasi. Set yang ke dua, untuk mengidentifikasi pengetahuan yang hilang dan gap antara pengetahuan dengan tujuan atau pencapaian dari organisasi

f. Tahap 6: Pemilihan Populasi dan Sample Penentuan untuk populasi pada penelitian ini dilakukan pada semua karyawan (census) pada organisasi yang menjadi studi kasus, mengingat jumlah elemen populasi sedikit (23 Karyawan) dan semua elemen populasi memiliki peran penting dalam Knowledge Management System.

g. Tahap 7: Pengumpulan Data

Pengumpulan data dan informasi melalui dua proses, dimana proses pertama data dan informasi diperoleh melalui studi lapangan, dilakukan dengan pengisian kuesioner dan wawancara kepada para responden. Proses kedua diperoleh dari studi literature dan tulisan ilmiah tentang knowledge management system baik sumber dari dalam negeri atau pun dari luar negeri.

h. Tahap 8: Hasil dan Pembahasan

Melakukan analisa dari hasil audit, kemudian menganalisa sejauh mana proses atau alur pengelolaan pengetahuan yang terjadi dengan mengacu pada model Knowledge Management Processes yang dikembangkan oleh Beccerra-Fernandez, Gonzalez, A. \& Sabherwal, R. (2004). Selanjutnya dijadikan sebagai landasan dalam pengembangan prototype knowledge management system pada organisasi. Dilakukan pengujian terhadap prototype yang telah dikembangkan dengan melakukan User Acceptance Test (UAT) berdasarkan user requirement dan mengacu pada knowledge management processes yang dikembangkan Beccerra-Fernandez, Gonzalez, A. \& Sabherwal, R. (2004).

i. Tahap 9: Kesimpulan dan Saran

Dalam tahap ini dilakukan penyimpulan dalam bentuk jawaban terhadap pertanyaan penelitian yang telah dinyatakan pada Pendahuluan, dimana hasil penelitian diringkas dalam bagian kesimpulan dan saran sebagai perbaikan atau pengembangan penelitian lebih lanjut yang dapat dilakukan

\section{Hasil dan Pembahasan}

Beberapa penelitian yang mengembangkan kerangka teoritis maupun pendekatan yang sudah diuji untuk Knowledge Management System telah dilakukan oleh para peneliti terdahulu. Kerangka tersebut di antaranya dikembangkan oleh Nonaka dan Takeuci Hirotaka,1995; Davenport \& Prusak, 1998; Liebowitz,1999; Wickramasinghe, N. \& Sharma, S., 2005; Alavi dan Leidner, 2001; Markus, 2001; Beccerra-Fernandez, Gonzalez, A. \&Sabherwal, R., 2004. Dimana kerangka tersebut cukup representative untuk menjelaskan bagaimana perilaku Knowledge Management System dapat diterapkan di dalam organisasi.

Berdasarkan kajian literatur yang digunakan mengidentifikasi permasalahan bahwa, masih banyak organisasi dalam pengelolaan pengetahuan (knowledge management) masih mengalami kesulitan atau kurang efektif dan efisien yang terbatas akan ruang dan waktu dimana transfer knowledge sebagian besar hanya melalui proses socialization (tacit to tacit knowledge). Knowledge Management bukan suatu piranti (tool) yang lebih baik, namun bagaimana mengetahui untuk melakukan sesuatu (transfer knowledge) dengan lebih baik

Diharapkan dengan dilakukan penelitian ini yang mengacu kepada penelitian tentang Knowledge Audit dan Knowledge Management Systems \& Processes ini dapat memberikan masukan kepada pihak management organisasi dalam mempermudah pengembangan Knowledge Management System agar dapat lebih efektif dan efisien. Dimana hasil penelitian ini dijadikan sebagai bentuk baku dari proses pengembangan Knowledge Management System pada organisasi, sehingga dapat meningkatkan daya saing organisasi ditengah persaingan yang semakin tinggi. 


\subsection{Hasil Audit}

\subsubsection{Profil Responden}

Pada organisasi terdapat 23 karyawan yang terdiri dari 1 orang Kepala Divisi, 2 orang Wakil Kepala Divisi, 1 orang Group head, 2 orang Relationship Manager, 12 orang Junior AO 1, 2 orang Junior Staff 1, 2 orang Pelaksana dan 1 orang sekretaris. Penulis menyebarkan 23 kuesioner Knowledge Audit kepada seluruh karyawan yang ada di organisasi.

\subsubsection{Analisa Hasil Wawancara dan Kuesioner Knowledge Audit}

Kuesioner terdiri dari dua bagian pertanyaan, bagian pertama terdiri dari 15 pertanyaan dan bagian kedua 13 pertanyaan. Kuesioner yang terkumpuldan terisi dengan lengkap sebanyak 16 kuesioner, profil responden dapat dilihat padaTabel 2, diketahui bahwa rata-rata karyawan pada organisasi kurang dari 2 tahun menjabat pada posisi masing-masing dan rata-rata sebagai Junior Staf.

Tabel 2. Profil Responden

\begin{tabular}{|l|l|l|}
\hline No & \multicolumn{1}{|c|}{ Jabatan } & Lama Bekerja \\
\hline 1 & Wakil Kepala Divisi & 2 Tahun \\
\hline 2 & Kepala Bagian & 10 Tahun \\
\hline 3 & Junior Staf & 7 Bulan \\
\hline 4 & Junior Staf & 1 Tahun \\
\hline 5 & Junior Staf & 1 Tahun \\
\hline 6 & Junior Staf & 6 Bulan \\
\hline 7 & Junior Staf & 6 Bulan \\
\hline 8 & Junior Staf & 8 Bulan \\
\hline 9 & Junior Staf & 2 Tahun \\
\hline 10 & Junior Staf & 2 Tahun \\
\hline 11 & Junior Staf & 1 Tahun \\
\hline 12 & Junior Staf & 2 Tahun \\
\hline 13 & Junior Staf & 2 Tahun \\
\hline 14 & Junior Staf & 6 Bulan \\
\hline 15 & Junior Staf & 6 Bulan \\
\hline 16 & Junior Staf & $\begin{array}{l}1 \text { Tahun } \\
6 \text { Bulan }\end{array}$ \\
\hline
\end{tabular}

Dari hasil kuesioner dan wawancara dapat disimpulkan bahwa, pada organisasi manajemen pengelolaan pengetahuan sudah baik, dimana terdapat tiga komponen penting orang/karyawan, organisasi dan proses, dijelaskan sebagai berikut:

1. briefing pagi, dimana setiap briefing dilakukan pencatatan pada sebuah buku berupa notulen rapat (knowledge sharing-externalization - tacit to explicit knowledge),

2. konsultasi kepada atasan, bertanya kepada rekan kerja, (knowledge sharing - sosialization - tacit to tacit knowledge),

3. Hasil dari konsultasi dengan atasan sebagai arahan dalam menyusun atau menganalisa kredit (knowledge application - direction).

4. Surat Edaran, Surat Keputusan, Executive Summary, Memorandum Analisa Kreditberupa berkas (knowledge discovery - combination - explicit to explicit knowledge, knowledge sharingexchange).

5. Penyimpanan pengetahuan dalam bentuk berkas yang dapat dipergunakan kembali sebagai acuan atau panduan dalam menyusun atau menganalisa kredit (knowledge capture - explicit knowledge).

6. Dan dari semua proses itu terulang terusmenerus (knowledge application routines).

Dari hasil kuesioner knowledge audit dan wawancara dapat diketahui mekanisme knowledge management dengan mengacu pada Knowledge Management Systems \& Processes (Beccerra-Fernandez, Gonzalez, A. \& Sabherwal, R. (2004) yang dijadikan acuan standar pengembangan knowledge management system dapat disimpulkan bahwa, pada organisasi manajemen pengelolaan pengetahuan organisasi sudah terdapat 7 sub proses pada Knowledge Management Systems \& Processes. Namun masih terbatas oleh ruang dan waktu karena proses sebagian besar secara langsung dengan tatap muka dan berkas berupa hardcopy dimana terdapat kesulitan dalam melakukan pencarian berkas tersebut.

Salah satu solusi dari sisi Information Technology (IT) yang dipaparkan BeccerraFernandez, Gonzalez, A. \& Sabherwal, R. (2004) dalam Knowledge Management Systems \& Processes salah satunya adalah menggunakan web application dalam proses konversi pengetahuan dan penyebaran pengetahuan dalam organisasi. Oleh karena itu dilakukan pengembangan Knowledge Management System berbasis teknologi 
informasi dalam pengelolaan dan proses transfer knowledge pada organisasi dengan mengacu pada Knowledge Management Systems \&Processes (Beccerra-Fernandez, Gonzalez, A. \& Sabherwal, R., 2004) berupa web application.

\subsection{Pengembangan dan Pengujian Model Knowledge Management System}

Dalam pengembangan model dilakukan dengan mengembangkan system dalam bentuk prototype menggunakan moodle, lebih dijelaskan sebagai berikut.

\subsubsection{Deskripsi User Requirement} IEEE 610.12-1990 mengenai Standard Glossary of Software Engineering mendefinisikan requirement sebagai berikut:

1. suatu kondisi atau kemampuan yang dibutuhkan oleh pengguna untuk memecahkan masalah atau mencapai suatu tujuan;

2. kondisi atau kemampuan yang harus dipenuhi atau dimiliki oleh sistem atau komponen sistem untuk memenuhi kontrak, standar, spesifikasi, atau lainnya secara resmi dan tertulis;

3. representasi terdokumentasi dari kondisi atau kemampuan seperti pada poin $t 1$ atau point 2.

Dengan menggunakan Knowledge Management System diharapkan dapat mendokumentasikan atau meng-capture tacit knowledge dan dalam penyebaran pengetahuan dapat dilakukan lebih efektif. Adapun User Requirement Knowledge Management System yang akan dikembangkan mengacu pada hasil Knowledge Audit yang telah dilakukan sebelumnya dan harus memenuhi 7 (tujuh) subproses Knowledge Management Systems \& Processes (Beccerra-Fernandez, Gonzalez, A. \& Sabherwal, R., 2004) yang dijadikan sebagai acuan standar dalam pengembangan.

Dari hasil audit dan wawancara dimana Knowledge Management Systems \& Processes yang dijadikan sebagai acuan standar dalam pengembangan, dapat diketahui potensi pengguna sebanyak 23 pengguna yang diklasifikasikan Manager dan Staff dijelaskan lebih lanjut pada tabel berikut.
Tabel 3. Klasifikasi Pengguna

\begin{tabular}{|l|c|c|}
\hline \multirow{2}{*}{ Wewenang } & \multicolumn{2}{c|}{ Pengguna } \\
\cline { 2 - 3 } & Manager & Staff \\
\hline $\begin{array}{l}\text { Membuat explicit } \\
\text { knowledge baru } \\
\text { (KnowledgeDiscovery) }\end{array}$ & $\mathrm{x}$ & $\mathrm{x}$ \\
\hline $\begin{array}{l}\text { Melakukan diskusi } \\
\text { (knowledge sharing) }\end{array}$ & $\mathrm{x}$ & $\mathrm{x}$ \\
\hline $\begin{array}{l}\text { Mengunggah dokumen } \\
\text { (knowledge capture- } \\
\text { externalization) }\end{array}$ & $\mathrm{x}$ & $\mathrm{x}$ \\
\hline $\begin{array}{l}\text { Mengunduh dokumen } \\
\text { (knowledge capture- } \\
\text { internalization) }\end{array}$ & $\mathrm{x}$ & $\mathrm{x}$ \\
\hline $\begin{array}{l}\text { Memberikan arahan } \\
\text { (knowledge application- } \\
\text { direction) }\end{array}$ & $\mathrm{x}$ & \\
\hline
\end{tabular}

Kemudian dalam penyebaran pengetahuan sebagian besar dilakukan dengan diskusi atau konsultasi, oleh karena itu disediakan fasilitas berupa forum diskusi dan chat room yang memungkinkan terjadi interaksi antar pengguna, serta dapat diakses kapanpun dan dimanapun.

Explicit knowledge yang ada masih dalam bentuk berkas (hardcopy) dilakukan pemindaian dengan tujuan konversi menjadi softcopy, kemudian fasilitas management document dalam web application dimana pengguna memungkinkan untuk mengunggah atau mengunduh dokumen, mencari dokumen sehingga memudahkan pengguna mempelajari dokumen yang ada sebagai tujuan dari konversi pengetahuan (User Requirement), dijelaskan lebih lanjut pada Tabel 4. 
Tabel 4. User Requirement

\begin{tabular}{|c|c|c|}
\hline Proses & Fasilitas & $\begin{array}{c}\text { Fungsi } \\
\text { yang } \\
\text { diharapkan }\end{array}$ \\
\hline \multicolumn{3}{|c|}{ Knowledge Discovery } \\
\hline $\begin{array}{ll}\text { a. } & \text { Combination } \\
& \text { (explicit to } \\
\text { explicit } \\
\text { knowledge) }\end{array}$ & $\begin{array}{l}\text { - Manageme } \\
\mathrm{nt} \\
\text { Documents }\end{array}$ & $\begin{array}{l}\text { Memungkinka } \\
\mathrm{n} \text { user dapat } \\
\text { membuat } \\
\text { explicit } \\
\text { knowledge } \\
\text { yang baru, } \\
\text { dari } \\
\text { knowledge } \\
\text { explicit } \\
\text { sebelumnya. }\end{array}$ \\
\hline $\begin{array}{ll}\text { b. } & \text { Socialization } \\
& \text { (tacit to tacit } \\
\text { knowledge) }\end{array}$ & $\begin{array}{l}\text { - } \text { Chat Room } \\
\text { - Forum } \\
\text { Diskusi }\end{array}$ & $\begin{array}{l}\text { Memungkinka } \\
\mathrm{n} \text { user untuk } \\
\text { dapat } \\
\text { melakukan } \\
\text { diskusi secara } \\
\text { real time } \\
\text { dengan user } \\
\text { lain }\end{array}$ \\
\hline \multicolumn{3}{|l|}{ Knowledge Capture } \\
\hline $\begin{array}{ll}\text { a. } & \text { Externalization } \\
& \text { (tacit to } \\
& \text { explicit } \\
& \text { knowledge) }\end{array}$ & $\begin{array}{l}\text { - Manageme } \\
\text { nt } \\
\text { Documents } \\
\text { - Forum } \\
\text { Diskusi }\end{array}$ & $\begin{array}{l}\text { Memungkinka } \\
\mathrm{n} \text { user untuk } \\
\text { dapat berbagi } \\
\text { tacit } \\
\text { knowledge }\end{array}$ \\
\hline $\begin{array}{ll}\text { b. Internalization } \\
\text { (explicit to } \\
\text { tacit } \\
\text { knowledge) }\end{array}$ & $\begin{array}{l}\text { - Manageme } \\
\text { nt } \\
\text { Documents } \\
\text { - Forum } \\
\text { Diskusi } \\
\text { - News }\end{array}$ & $\begin{array}{l}\text { Memungkinka } \\
\mathrm{n} \text { user untuk } \\
\text { mendapatkan } \\
\text { pemahaman } \\
\text { dari explicit } \\
\text { knowledge } \\
\text { yang ada. }\end{array}$ \\
\hline \multicolumn{3}{|l|}{ Knowledge Sharing } \\
\hline $\begin{array}{ll}\text { a. } & \text { Socialization } \\
& \text { (tacit to tacit } \\
& \text { knowledge })\end{array}$ & $\begin{array}{l}\text { - } \text { Chat Room } \\
\text { - Forum } \\
\text { Diskusi }\end{array}$ & $\begin{array}{l}\text { Memungkinka } \\
\mathrm{n} \text { user untuk } \\
\text { dapat } \\
\text { melakukan } \\
\text { diskusi secara } \\
\text { real time } \\
\text { dengan user } \\
\text { lain }\end{array}$ \\
\hline
\end{tabular}

\begin{tabular}{|c|c|c|}
\hline $\begin{array}{ll}\text { b. } & \text { Exchange } \\
& \text { (explicit to } \\
& \text { explicit } \\
& \text { knowledge) }\end{array}$ & $\begin{array}{l}\text { - Managemen } \\
t \\
\text { Documents } \\
\text { - News }\end{array}$ & $\begin{array}{l}\text { Memungkinka } \\
\mathrm{n} \text { user dapat } \\
\text { membuat } \\
\text { explicit } \\
\text { knowledge } \\
\text { baru yang } \\
\text { lebih baik dari } \\
\text { knowledge } \\
\text { explicit } \\
\text { sebelumnya. }\end{array}$ \\
\hline \multicolumn{3}{|c|}{ Knowledge Application } \\
\hline a. Direction & Forum Diskusi & $\begin{array}{l}\text { Memungkinka } \\
\mathrm{n} \text { seorang ahli } \\
\text { (Manager/Atas } \\
\text { an) dapat } \\
\text { memberikan } \\
\text { arahan pada } \\
\text { forum diskusi }\end{array}$ \\
\hline b. Routines & $\begin{array}{l}\text { Web dinamis } \\
\text { yang user } \\
\text { friendly }\end{array}$ & $\begin{array}{l}\text { Memungkinka } \\
\mathrm{n} \text { user untuk } \\
\text { mudah } \\
\text { memahami, } \\
\text { mempelajari } \\
\text { dan } \\
\text { mengoperasik } \\
\text { an aplikasi }\end{array}$ \\
\hline
\end{tabular}

Dalam pengembangan Knowledge Management System interaksiuser dengan sistem digambarkan dalam Use Case Diagram sebagai berikut:

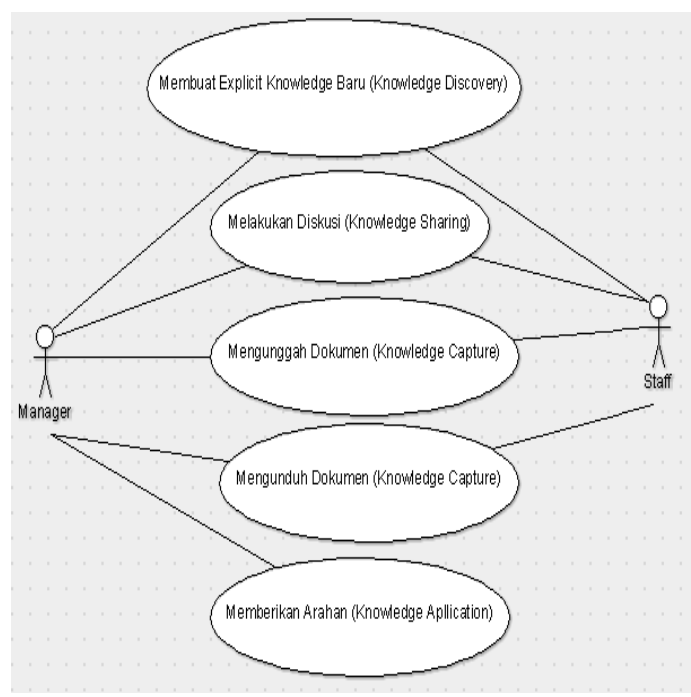

Gambar 2. Use Case Diagram 


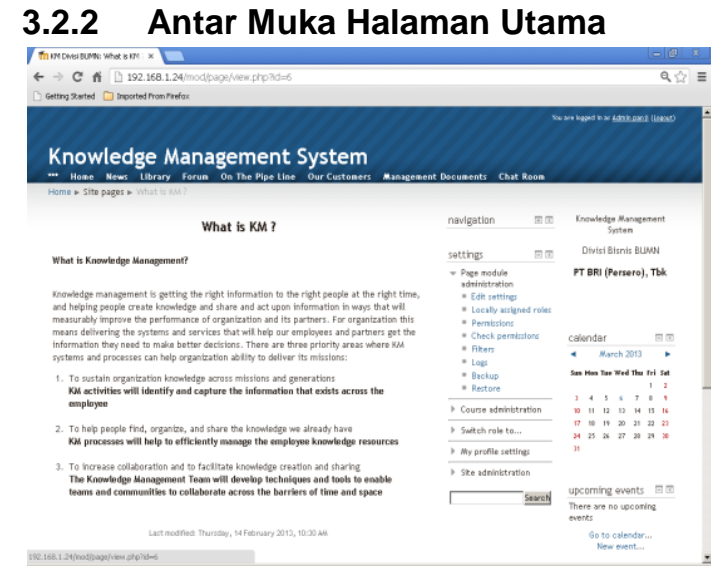

Gambar 3. Antar Muka Halaman Utama

\subsubsection{Antar Muka Halaman Login}

Antar muka ini berfungsi sebagai pintu gerbang untuk memasuki knowledge Management System ini, terdiri dari Username dan Password.Apabila Username dan password telah sesuai, maka user dapat menggunakan fasilitas yang disediakan sesuai kewenangan.

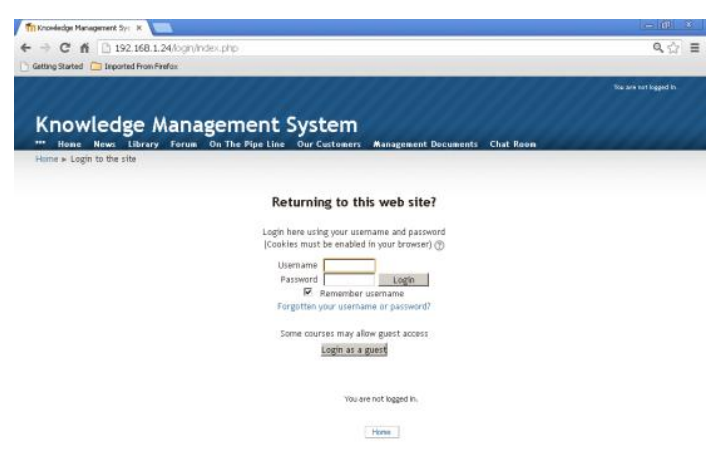

Gambar 4. Antar Muka Halaman Login

\subsubsection{Antar Muka Halaman Chat Room (Knowledge Discovery System- Socialization) \\ Pada Knowledge Management} Processes terdapat proses Knowledge Discovery System yang mendukung pengembangan tacit dan explicit knowledge yang baru, dimana berasal dari data dan informasi atau dari perpaduan pengetahuan sebelumnya. Knowledge Discovery System tergantung kepada mekanisme dan teknologi yang mendukung proses combination (explicit to explicit knowledge) dan proses socialization (tacit to tacit knowledge).

Proses socialization merupakan perpaduan antara tacit knowledge antar individu, yang tertuang dalam bentuk kegiatan secara lisan atau tulisan. Socialization dapat berlangsung dalam sebuah diskusi. Seperti dilakukan Honda yang mendirikan brainstorming camp untuk mencari pemecahan masalah dalam penelitian dan pengembangan project (Nonaka dan Takeuci, 1995). Oleh karena itu ditarik kesimpulan, dalam pengembangan sebuah Knowledge Management System direkomendasikan terdapat fasilitas forum diskusi sebagai fasilitas untuk brainstorming antar individu pada organisasi.

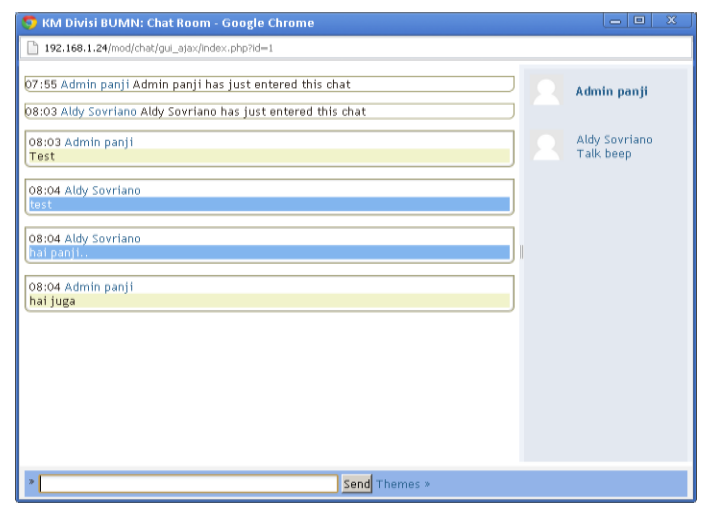

Gambar 5. Antar Muka Halaman Chat Room

\subsubsection{Antar Muka Halaman News-Our Customers dan Management Documents (Knowledge Discovery System-Combination)}

Proses combination merupakan suatu proses yang bertujuan untuk menciptakan explicit knowledge yang baru. Berupa explicit knowledge yang lebih kompleks, dari berbagai explicit knowledge (data dan informasi) yang tersedia dan terpadu menjadi sebuah explicit knowledge yang baru (Irma Becerra - Fernandez,et.al., 2004). Hal ini dapat didukung dengan adanya fasilitas yang memungkinkan untuk mengunggah dan mengunduh file kedalam suatu database. Pada halaman Documents tersedia fasilitas unggah file Surat Masuk, Surat Keluar, Surat Edaran, Surat Keputusan, Executive Summary, Memorandum Analisa Kredit, Pencairan Kredit, Portofolio Bisnis, dan lain-lain, dalam bentuk wiki files. 


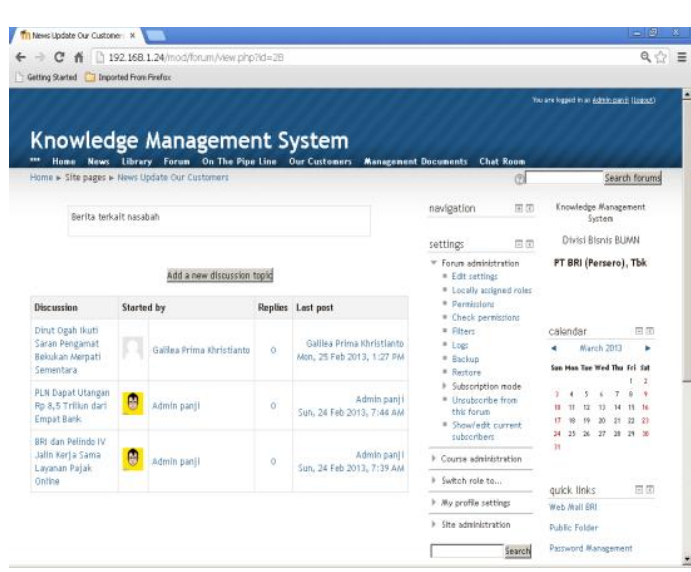

Gambar 6. Antar Muka Halaman News Our Customers

\subsubsection{Antar Muka Halaman Forum Idea and Complaint Handling (Knowledge Capture System)}

Knowledge Capture System dirncang untuk membantu mendapatkan dan menyimpan pengetahuan organisasi dan individu, termasuk tacit dan explicit knowledge.Pengetahuan dapat di-capture menggunakan mekanisme dan teknologi, dimana pengetahuan yang telah di-capture dapat disebarkan dan digunakan oleh karyawan lain (internalization - explicit to tacit knowledge). Dengan berbagi pengalaman (storytelling) dari individu/karyawan atau generasi sebelumnya yang telah mengalami situasi tertentu, yang mendapatkan pembelajaran dan pengetahuan dari situasi tersebut baik secara tertulis atau pun lisan (externalization - tacit to explicit knowledge).

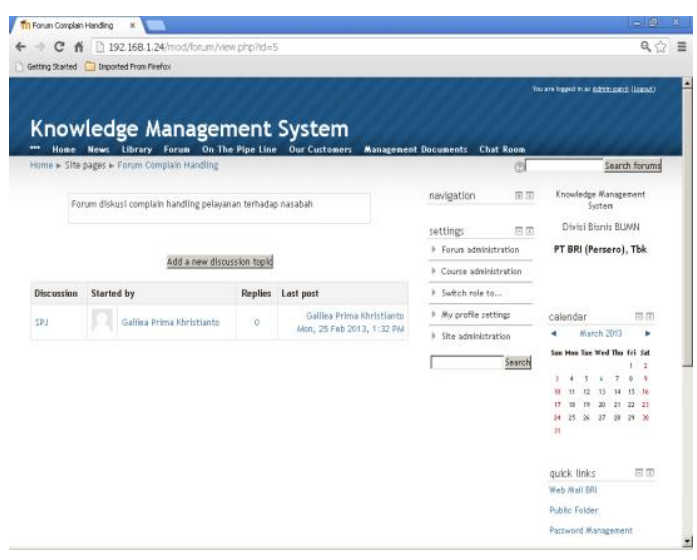

Gambar 7. Antar Muka Halaman Forum Idea and Complaint Handling

Hal ini akan meminimalisir kesalahan atau kekurangan pada masa yang akan datang, apabila terdapat situasi yang sama atau mendekati situasi tersebut. Untuk memfasilitasi Knowledge Capture System disediakan forum idea and complain handling yang memungkinkan setiap individu/karyawan berbagi ide-ide dan pengalaman (storytelling).

\subsubsection{Antar Muka Halaman Management Documents (Knowledge Sharing System)}

Knowledge sharing merupakan proses komunikasi tacit dan explicit knowledgeantar individu/karyawan, yang sangat penting dalam meningkatkan inovasi dan kinerja organisasi. Dalam Knowledge Sharing System tergantung kepada mekanisme dan teknologi yang mendukung proses socialization (tacit to tacit knowledge) seperti pada proses knowledge discovery dan proses exchange.

Proses exchange terlihat jelas fokus pada berbagi explicit knowledge, proses ini digunakan untuk mengkomunikasikan atau mentransfer explicit knowledge diantara individu, group dan organisasi (Grant, 1996a).

Untuk memfasilitasi Knowledge Sharing System disediakan fasilitas unggah file dan management dokumen (kearsipan), dimana setiap individu dapat mengunggah file dan dokumen yang telah dibuat sebelumnya, termasuk surat masuk, surat keluar, surat edaran, surat keputusan, executive summary, Memorandum Analisa Kredit (MAK), pencairan kredit, protofolio bisnis, dan lain-lain. Yang dapat digunakan sebagai acuan atau dasar dalam melakukan analisa bisnis.

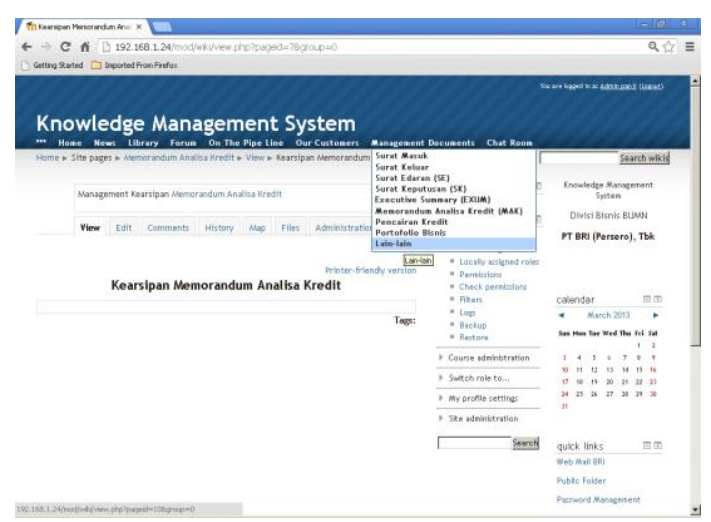

Gambar 8. Antar Muka Halaman Management Documents 


\subsubsection{Antar Muka Halaman On The Pipe Line (Knowledge Application System)}

Proses knowledge application tergantung dari proses-proses sebelumnya yaitu knowledge discovery, knowledge capture dan proses penyimpanan. Dimana semakin baiknya proses knowledge discovery, knowledge capture dan proses penyimpanan, semakin besar kemungkinan pengetahuan tersebut di butuhkan dalam pengambilan keputusan yang lebih efektif.
Dalam proses penerapan pengetahuan, terdapat subproses direction yang difasilitasi dengan adanya forum yang memungkinkan user memaparkan apa yang sedang dikerjakan dan memungkinkan atasan untuk memberikan arahan (direction). Yang diharapkan dapat menjadi suatu sistem yang dilakukan secara rutin (routine). Pada pengembangan Knowledge Management System disediakan fasilitas forum On ThePipe Line, Seperti dapat dilihat pada Gambar 9 berikut.

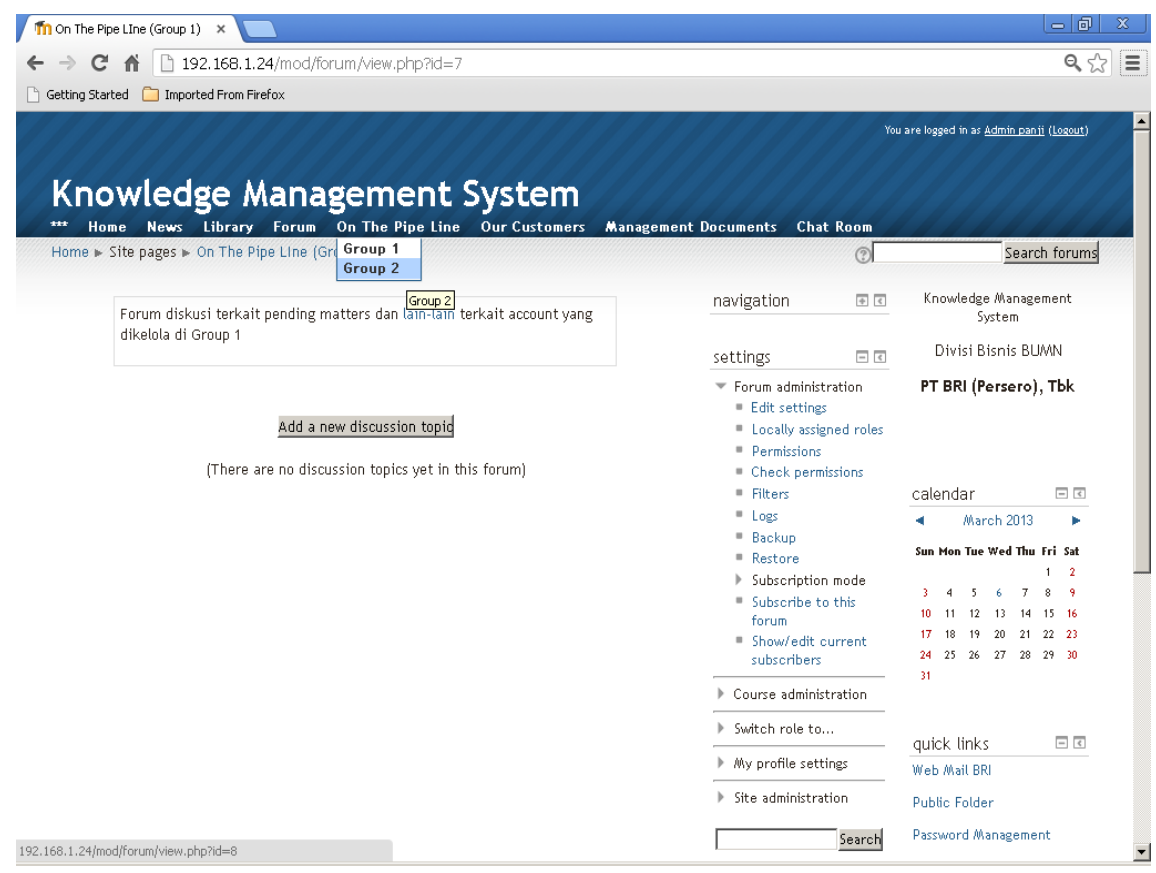

\section{Gambar 9. Antar Muka Halaman Forum On The Pipe Line \\ 3.2.9 Hasil Pengujian Prototype dikembangkan sudah sesuai dengan User Knowledge Management System Requirement. Dapat dilihat pada Tabel 4. \\ Proses pengujian perangkat lunak Knowledge management system dibangun (prototype Knowledge Management System) dalam bentuk prototype, setelah dilakukan dengan melakukan User dilaksanakan UAT (User Acceptance Test) Acceptance Test (UAT) mengacu pada User diketahui hasil yang diharapkan Requirement yang berdasarkan hasil sesuaidengan user reqruirement dan Knowledge Audit yang telah dilakukan metode knowledge management processes sebelumnya dan Knowledge Management (berita acara UAT terlampir), hasil dari uji Processes (Beccerra-Fernandez, Gonzalez, coba dapat dilihat pada Tabel 5.}

A. And Sabherwal, R. 2004).

\subsubsection{Materi dan Hasil Uji Coba Knowledge Management System \\ Pengujian diikuti 6 user sebagai pengamat yang diambil secara acak, penilaian dilakukan dengan pengujian pada sistem berjalan, dimana user melakukan penilaian apakah sistem yang}


Tabel 5. Hasil Uji Coba Knowledge Management System

\begin{tabular}{|c|c|c|c|}
\hline No & Materi Uji Coba & Konversi Pengetahuan & Hasil Yang Diharapkan \\
\hline & Add User & & Admin dapat menambahkan user baru \\
\hline 2 & Add news "Warta BRI" & (explicit to tacit knowledge) & $\begin{array}{l}\text { Admin dapat menambahkan berita-berita } \\
\text { bisnis perbankan dan yang terkait } \\
\text { organisasi, serta dapat diakses semua }\end{array}$ \\
\hline 3 & View "Library" & (explicit to tacit knowledge) & $\begin{array}{l}\text { Semua user dapat mengakses ke library } \\
\text { (Produk dan Jasa) }\end{array}$ \\
\hline 4 & $\begin{array}{l}\text { Add New "Topic Forum } \\
\text { Idea \& Complaint } \\
\text { Handling" }\end{array}$ & (tacit to explicit knowledge) & $\begin{array}{l}\text { Semua cser dapat mengakses dan } \\
\text { menambah topik pembahasan pada forum }\end{array}$ \\
\hline 5 & $\begin{array}{l}\text { Add New Topic "Forum } \\
\text { Produk dan Jasa" }\end{array}$ & (tacit to explicit knowledge) & $\begin{array}{l}\text { Semua user dapat mengakses dan } \\
\text { menambah topik pembahasan pada forum }\end{array}$ \\
\hline 6 & $\begin{array}{l}\text { Add New Topic "On The } \\
\text { Pipe Line" }\end{array}$ & (tacit to explicit knowledge) & $\begin{array}{l}\text { Semua user dapat mengakses dan } \\
\text { menambah topik pembahasan pada forum }\end{array}$ \\
\hline & $\begin{array}{l}\text { Add New Topic "Our } \\
\text { Customers" }\end{array}$ & (tacit to explicit knowledge) & $\begin{array}{l}\text { Semua user dapat mengakses dan } \\
\text { menambah topik pembahasan pada forum }\end{array}$ \\
\hline 8 & $\begin{array}{l}\text { Upload File "Management } \\
\text { Documents" }\end{array}$ & (explicit to explicit knowledge) & Semua user dapat mengunggah file \\
\hline 9 & Simplicity & & $\begin{array}{l}\text { user mudah memahami, mempelajari dan } \\
\text { mengoperasikan aplikasi }\end{array}$ \\
\hline
\end{tabular}

\section{Kesimpulan}

Berdasarkan perancangan, pembahasan dan kajian yang dilakukan sebagaimana diuraikan dalam penelitian ini, maka dapat diambil beberapa kesimpulan bahwa Penelitian ini telah berhasil mempermudah transfer knowledge didalam perusahaan melalui pengembangan knowledge management system berbasis knowledge audit dengan knowledge management processes sebagai standar pengembangan. Audit yang dihasilkan telah mampu mengidentifikasi kompetensi dan kapabilitas dari karyawan, serta mengoptimalisasi mekanisme knowledge management yang ada di organisasi. Beberapa saran yang diajukan berkenaan dengan penelitian ini bahwa Knowledge management system yang dibangun dalam bentuk prototype masih merupakan model awal yang belum secara utuh memasukkan basis pengetahuan bagi organisasi. Dengan demikian basis pengetahuan yang ada di dalam prototype knowledge management system ini perlu dikembangkan untuk dapat lebih efektif.Prototype knowledge management system ini perlu dikembangkan lagi untuk dapat berkolaborasi dengan organisasi terkait, agar basis pengetahuan lebih luas dan transfer knowledge yang lebih efektif. Dilakukan audit secara berkala untuk pembaharuan baik secara mekanisme atau basis pengetahuan yang telah ada.

\section{Referensi}

Amidon, D. M. (2002). The Innovation SuperHighway. Frontiers of Entrepreneurship and Innovation: Readings in Science Park Policies and Practices. International Association of Science Parks.
Alavi, M. And Leidner D., (2001). Review Knowledge Management and Knowledge Management Systems : Conceptual Fundations and Research Issues. MIS Quarterly, Vol 25 No.1. pp. $571-82$

Beccerra-Fernandez, Gonzalez, A. And Sabherwal, R. (2004). Knowledge Management : Challenges, Solutions, and Technologies, Prentice Hall, London.

Davenport, T.H, \& Grover V., (2001). General Perspectives on Knowledge Management : Fostering a Research Agenda. Jurnal of Management Information Systems. Vol. 18, pp. 5-21.

Davenport, T.H, \& Prusak, L, (1988) Working Knowledge : How Organizations Manage What They Khow. Harvard Bussiness School Press

Grant, R. M., (1996a), Prospering in Dynamically Competitive Environments:Organizational Capability as Knowledge Integration. Organization Science, 7(4), pp 375-387

Grant, R. M., (1996b), Toward a KnowledgeBased Theory of The Firm. Strategic Management Journal, 17, pp 109-122

Leibowitz, J. and Beckman, (1998). Knowledge Organizations: What Every Manager Should Know. St. Lucie Press. LLC, Boca Raton.

Liebowitz, J., Montano, B.R., McCaw, D., Buchwalter, J., \& Browning C,.(2007). The Knowledge Audit, ABI/INFORM Global, pg. 3. 
Nonaka, Ikujiro \& Tahachi, Hirotaka. 1995. The Knowledge-Creating Company: How Japanese Compainies Create the Dynamics of Innovation . Oxford: Oxford University Press.

Peter F. Drucker (1998) "The Coming of the New Organization" in Harvard Business Review on Knowledge Management. Harvard Business School Press. pp. 119.

Specht, G., Beckmann,Ch., \& Amelingmeyer, J. (2002). F\&EManagement. Stuttgart: SchäfferPoeschel-Verlag.

Setiarso, Bambang dkk. (2009) . “ Penerapan Knowledge Management Pada Organisasi. Graha IImu, Yogyakarta.

Wickramasinghe, N. \& Sharma, S., (2005). The Fundamentals of Knowledge Management. Upper Saddle River, NJ, Prentice Hall. 